\title{
Bacteriophage lysins as antibacterials
}

\author{
Umender Sharma* (1) and Vivek D. Paul \\ See related Editorial by Opal et al., http://ccforum.biomedcentral.com/articles/10.1186/s13054-016-1549-1
}

We read the editorial entitled "Non-antibiotic treatments for bacterial diseases in an era of progressive antibiotic resistance" by Steven M. Opal published in Critical Care [1]. We want to congratulate the author for this timely editorial and appreciate the efforts to highlight various non-antibiotic-based approaches being pursued for treating drug-resistant bacteria. We fully agree that there is a need to consider these approaches as serious alternatives to conventional antibiotics.

In the editorial, six possible options have been listed as non-antibiotic inhibitors of bacterial growth. We agree that these are viable options which include devices and chemical or biological compounds for addressing the problem of bacterial drug-resistance. Although we understand that this is not an exhaustive list of possible options, we would like to suggest that bacteriophage "lysins", including both endolysins (which help the phage in releasing the intracellular virus particles by cleaving the peptidoglycan from inside) and ectolysins (which help the phage in injecting DNA into the bacterial cell by cleaving the peptidoglycan on the external surface) can also be considered as alternative options for treating drug-resistant bacteria. When added to a bacterial culture in broth or buffer, the lysins kill bacteria rapidly by cleaving peptidoglycan, a cell wall component specific to bacteria. Because of their specific nature, lysins kill only the target bacteria and thus do not alter the microbiome. Lysins can be easily produced in Escherichia coli as recombinant proteins and properties such as rapid killing, specificity, ability to kill antibiotic persisters, low rates of resistance and profound antibiofilm activity [2-4] make them good candidates for clinical development for treating serious infections. Several lysins such as CF-301, N-Rephasin, P128 and Art-175 are in various stages of advanced pre-clinical or clinical development as antibacterials for treating infections caused by drug-resistant Gram-positive and Gram-negative pathogens [3-5]. Antibacterial efficacy of a number of lysins has been demonstrated in relevant animal models and it has also been observed that the presence of anti-lysin antibodies does not impact the lysin efficacy in vivo [6]. Thus, keeping in mind the recent advances made in the area of discovery and clinical development of phage lysins to combat drug-resistant bacteria, we propose that lysins should also be highlighted as alternative options under the "non-antibiotic" approaches.

\section{Author's response}

Steven M. Opal

I heartily agree with the comments made by Sharma and Paul regarding the potential contribution of phagemedicated endolysin as a novel therapeutic option against multiple antibiotic drug-resistant (MDR) bacterial pathogens. Phage employ a two-component enzyme system, known as holin and endolysin, to allow newly generated phage progeny to exit the dying bacterial cell and invade other susceptible host cells. Holin is a bacterial cell membrane permeablizing enzyme that creates pores within the inner membrane of bacteria, while endolysin destroys the cross-linking of the peptidoglycan

\footnotetext{
* Correspondence: Umender@gangagen.com; umender1912@gmail.com GangaGen Biotechnologies Pvt Ltd, Yeshwantpur, Bangalore, India
}

layer that constitutes the outer membrane. Holin sets the pace of lysis to correspond to the maximum rate of phage synthesis just before the parasitized bacterial cell dies. At that moment endolysin floods the outer membrane, thereby lysing the cell allowing the new generation of phage particles to be released into the environment [7].

Recombinant forms of lysins have been synthesized and are now being used therapeutically in experimental models of bacterial infection [3, 7-9]. Their protective activity is impressive with clearance rates of bacterial pathogens that rival standard antibiotics. This antibiotic-independent, lytic enzyme should be fully active against MDR pathogens [3, 7-9]. If clinical testing can assure safety and efficacy of this 
highly potent antibacterial peptide, lysin therapy might become a welcome addition to our dwindling options to treat MDR pathogens.

\section{Abbreviations}

MDR: Multiple antibiotic drug-resistant

\section{Acknowledgements}

Not applicable.

\section{Funding}

No funding was provided for this letter.

\section{Availability of data and materials}

Not applicable.

\section{Authors' contributions}

US and VDP wrote and edited the letter and both authors read and approved the final version of the manuscript.

\section{Authors' information}

US and VDP are employees of GangaGen Biotechnologies Pvt Ltd, Bangalore, India.

\section{Competing interests}

The authors declare that they have no competing interests.

\section{Consent for publication}

Not applicable.

\section{Ethics approval and consent to participate}

Not applicable.

\section{Publisher's Note}

Springer Nature remains neutral with regard to jurisdictional claims in published maps and institutional affiliations.

Published online: 03 May 2017

\section{References}

1. Opal SM. Non-antibiotic treatments for bacterial diseases in an era of progressive antibiotic resistance. Crit Care. 2016;20:397.

2. Schuch R, Lee HM, Schneider BC, Sauve KL, Law C, Khan BK, Rotolo JA, Horiuchi Y, Couto DE, Raz A, Fischetti VA, Huang DB, Nowinski RC, Wittekind M. Combination therapy with lysin CF-301 and antibiotic is superior to antibiotic alone for treating methicillin-resistant Staphylococcus aureusinduced murine bacteremia. J Infect Dis. 2014;209:1469-78.

3. Nair S, Desai S, Poonacha N, Vipra A, Sharma U. Antibiofilm activity and synergistic inhibition of S. aureus biofilms by bactericidal protein P128 in combination with antibiotics. Antimicrob Agents Chemother. 2016;60:7280-9.

4. Briers Y, Walmagh M, Grymonprez B, Biebl M, Pirnay JP, Defraine V, Michiels J, Cenens W, Aertsen A, Miller S, Lavigne R. Art-175 is a highly efficient antibacterial against multidrug-resistant strains and persisters of Pseudomonas aeruginosa. Antimicrob Agents Chemother. 2014;58:3774-84.

5. Czaplewski L, Bax R, Clokie M, Dawson M, Fairhead H, Fischetti VA, Foster S, Gilmore BF, Hancock RE, Harper D, Henderson IR, Hilpert K, Jones BV, Kadioglu A, Knowles D, Ólafsdóttir S, Payne D, Projan S, Shaunak S, Silverman J, Thomas CM, Trust TJ, Warn P, Rex JH. Alternatives to antibioticsa pipeline portfolio review. Lancet Infect Dis. 2016;16:239-51.

6. Zhang L, Li D, Li X, Hu L, Cheng M, Xia F, Gong P, Wang B, Ge J, Zhang H, Cai R, Wang Y, Sun C, Feng X, Lei L, Han W, Gu J. LysGH15 kills Staphylococcus aureus without being affected by the humoral immune response or inducing inflammation. Sci Rep. 2016;6:29344.

7. Schmelcher M, Loessner MJ. Bacteriophage endolysins: applications for food safety. Curr Opin Biotechnol. 2016;37:76-87.

8. Fischetti VA. Bacteriophage endolysins: A novel anti-infective to control Gram-positive pathogens. Int J Med Microbiol. 2010;300(6):357-62.

9. Schmelcher M, Donovan DM, Loessner MJ. Bacteriophage endolysins as novel antimicrobials. Future Microbiol. 2012;7(10):1147-71. 